\title{
The efficacy of $\mathrm{Li}$ in bipolar disorder
}

This article was published in the following Dove Press journal:

Neuropsychiatric Disease and Treatment

10 July 2013

Number of times this article has been viewed

R Lozano'

R Marín ${ }^{2}$

MJ Santacruz ${ }^{2}$

I Freire ${ }^{2}$

R Gomez ${ }^{2}$

'Department of Pharmacy, ${ }^{2}$ Department of Psychiatry, Hospital Real Nuestra Señora de Gracia, Zaragoza, Spain
Correspondence: R Lozano

Department of Pharmacy, Hospital Real Nuestra Señora de Gracia,

Ramon y cajal, 6050004 Zaragoza, Spain

Tel +34876 764522

Fax +34876764555

Email rlozano@salud.aragon.es

\section{Dear editor}

The efficacy of lithium (Li) for acute mania and as prophylaxis against recurrent episodes of mania in bipolar disorder has been well established, with the minimum effective Li serum concentration for acute mania in the range of $0.6-1.2 \mathrm{mEq} / \mathrm{L}$, although lower maintenance concentrations can prove effective in some patients. ${ }^{1-5}$

Thyroid disorders are also associated with alterations in mood, and patients with hypothyroidism may present with depression and cognitive dysfunction, ${ }^{6-8}$ while patients with hyperthyroidism may present with anxiety, depression, mood lability, ${ }^{79}$ and manic symptoms. ${ }^{10}$ However, considering that overt hyperthyroidism is uncommon in bipolar disorder, with a prevalence $\leq 2 \%$ across different studies, ${ }^{11,12}$ this has been largely attributed to lithium, ${ }^{13}$ with rates varying from 0 to $47 \%$ (average of about $10 \%$ ) among patients on long-term treatment with lithium. ${ }^{13-16}$

Due to this association between thyroid disease and mood disorders (including bipolar disorder), an evaluation of thyroid function is made by psychiatrists before the diagnosis of any depressive or manic events and regularly evaluated during $\mathrm{Li}$ treatment. Furthermore, thyroid dysfunction is more common in patients with rapid cycling bipolar disorder or mixed states. ${ }^{17}$ In addition, levothyroxine treatment may decrease the severity and frequency of manic and depressive episodes, ${ }^{18}$ and patients with hyperthyroidism may also be associated with long-term mood disturbances. ${ }^{19}$

In this way, there are currently enough data about effects of Li on the thyroid, making it clear that Li affects the thyroid gland of all patients in a dose-dependent manner, with greater or lesser intensity. ${ }^{20,21}$ The levels of free thyroxine (FT4) have been used as a secondary surrogate marker, added to Li plasma levels, for Therapeutic Drug Monitoring of $\mathrm{Li}^{22}$

Thus, taking into account the changes that Li produces on the thyroid gland, and its relation to depressive and/or manic symptoms, it is evident that to give maximum validity to any current clinical study concerning the therapeutic and/or pharmacological activities of Li, the following should be considered: the initial and final thyroid status of patients; the use of equi-effective doses of Li with FT4 values in the range 1.0$1.1 \mathrm{mEq} / \mathrm{L} ;{ }^{22}$ stratification of patients according to thyroid activity. In this manner, we will avoid bias, caused by the activity of the thyroid gland, in depressive and/or manic symptoms present in bipolar patients (with or without Li treatment) under study.

In conclusion, there are methodological hurdles still to be overcome in the standardization of clinical study design in bipolar disorder, with thyroid gland 
abnormalities being one of the principal areas of variability, documented among patients with bipolar disorder, as well as patients on Lithium treatments.

\section{Disclosure}

The author reports no conflict of interest in this work.

\section{References}

1. Prien RF, Caffey EM Jr, Klett CJ. Relationship between serum lithium level and clinical response in acute mania treated with lithium. Br J Psychiatry. 1972;120:409-414.

2. Prien RF, Caffey EM Jr. Relationship between dosage and response to lithium prophylaxis in recurrent depression. Am J Psychiatry. 1976;133(5):567-570.

3. Stokes PE, Shamoian CA, Stoll PM, Patton MJ. Efficacy of lithium as acute treatment of manic-depressive illness. Lancet. 1971;1(7713): $1319-1325$.

4. Stokes PE, Kocsis JH, Arcuni OJ. Relationship of lithium chloride dose to treatment response in acute mania. Arch Gen Psychiatry. 1976;33(9): 1080-1084

5. Gold D, Walker G. Lithium failure: non-responders versus subtherapeutics levels. Hosp Formul. 1982;17:561-567.

6. Hendrick V, Altshuler L, Whybrow P. Psychoneuroendocrinology of mood disorders. The hypothalamic-pituitary-thyroid axis. Psychiatr Clin North Am. 1998;21(2):277-292.

7. Bauer M, Goetz T, Glenn T, Whybrow PC. The thyroid-brain interaction in thyroid disorders and mood disorders. $J$ Neuroendocrinol. 2008;20(10):1101-1114.

8. Bunevicius R, Prange AJ Jr. Thyroid disease and mental disorders: cause and effect or only comorbidity? Curr Opin Psychiatry. 2010; 23(4):363-368.

9. Bauer M, Whybrow PC. Thyroid hormone, brain, and behaviour. In: Pfaff DW, Arnold AP, Fahrbach SE, Etgen AM, Rubin RT, editors. Hormones, Brain and Behavior. New York: Academic Press; 2002: 238-264.
10. Lee CS, Hutto B. Recognizing thyrotoxicosis in a patient with bipolar mania: a case report. Ann Gen Psychiatry. 2008;7:3.

11. Ezzaher A, Neffati F, Mechri A, Douki W, Gaha L, Najjar MF. Evaluation of thyroid function in bipolar patients. Clin Chem Lab Med. 2009;47 (S371).

12. Bandyopadhyay D, Nielsen C. Lithium-induced hyperthyroidism, thyrotoxicosis and mania: a case report. QJM. 2012;105(1):83-85.

13. Bocchetta A, Loviselli A. Lithium treatment and thyroid abnormalities. Clin Pract Epidemiol Ment Health. 2006;2:23.

14. Lazarus JH. Lithium and thyroid. Best Pract Res Clin Endocrinol Metab. 2009;23(6):723-733.

15. Kirov G. Thyroid disorders in lithium-treated patients. J Affect Disord. 1998;50(1):33-40.

16. Johnston AM, Eagles JM. Lithium-associated clinical hypothyroidism. Prevalence and risk factors. Br J Psychiatry. 1999;175:336-339.

17. Chang KD, Keck PE Jr, Stanton SP, McElroy SL, Strakowski SM, Geracioti TD Jr. Differences in thyroid function between bipolar manic and mixed states. Biol Psychiatry. 1998;43(10):730-733.

18. Bauer MS, Whybrow PC. Rapid cycling bipolar affective disorder. II. Treatment of refractory rapid cycling with high-dose levothyroxine: a preliminary study. Arch Gen Psychiatry. 1990;47(5): 435-440.

19. Thomsen AF, Kessing LV. Increased risk of hyperthyroidism among patients hospitalized with bipolar disorder. Bipolar Disord. 2005;7(4):351-357.

20. Ozsoy S, Mavili E, Aydin M, Turan T, Esel E. Ultrasonically determined thyroid volume and thyroid functions in lithium-naïve and lithiumtreated patients with bipolar disorder: a cross-sectional and longitudinal study. Hum Psychopharmacol. 2010;25(2):174-178.

21. Roberto L. Lithium clearly and directly affects the activity of the thyroid gland in human. Hum Psychopharmacol. 2010;25(7-8):586.

22. Lozano R, Marin R, Pascual A, Santacruz MJ, Lozano A, Sebastian F. Biomarkers and therapeutic drug monitoring in psychiatry. In: Kumar T, editor. Biomarker. Rijeka: InTech; 2012:155-179.

23. Henry C, Andreassen OA, Barbato A, et al. European Network of Bipolar Research Expert Centre (ENBREC): a network to foster research and promote innovative care. International Journal of Bipolar Disorders. 2013;1:2.
Neuropsychiatric Disease and Treatment

\section{Publish your work in this journal}

Neuropsychiatric Disease and Treatment is an international, peerreviewed journal of clinical therapeutics and pharmacology focusing on concise rapid reporting of clinical or pre-clinical studies on a range of neuropsychiatric and neurological disorders. This journal is indexed on PubMed Central, the 'PsycINFO' database and CAS.

\section{Dovepress}

The manuscript management system is completely online and includes a very quick and fair peer-review system, which is all easy to use. Visit http://www.dovepress.com/testimonials.php to read real quotes from published authors. 